\title{
Die meting van die suurstofbindingseienskappe van hemosianien met die hulp van 'n dunlaag optiese sel
}

\author{
W.J. van Aardt \\ Departement Dierkunde, Potchefstroomse Universiteit vir Christelike Hoër Onderwys, Potchefstroom 2520
}

Ontvang 28 Oktober 199/; aanvaar /2 Januarie 1992

\section{UITTREKSEL}

Die meriete van die dunlaagmetode van Dolman en $\mathrm{Gill}^{7} \mathrm{om}$ die suurstofbindingseienskappe van hemosianien te meet, is met hemosianien afkomstig van arthropode en molluske getoets. Spektrofotometries is bevind dat oksihemosianien van sowel arthropode as molluske 'n prominente absorpsiepiek tussen $335 \mathrm{~nm}$ en $345 \mathrm{~nm}$ besit. Die resultate toon dat in vergelyking met hemoglobien hemosianien 'n beter stabiliteit in 'n dunlaagkonfigurasie besit. By $35^{\circ} \mathrm{C}$ verminder die aanvanklike absorbansiewaarde met minder as $2 \%$ na drie uurblootstelling. Vir hemoglobien by $35^{\circ} \mathrm{C}$ is die absorbansievermindering byna $10 \%$. By 'n hoëaffiniteithemosianien van byvoorbeeld Marisa cornuarietis $\left(P_{50}=1,07 \mathrm{mmHg}\right)$ is Dolman en Gill ${ }^{7}$ se metode ook beter as ander metodes, omrede ' $n$ verdunningsklep die $\mathrm{PO}_{2}$-waardes by hierdie lae suurstofspannings noukeuriger kan uitmeet. In hierdie studie word ' $n$ stap vir stap uiteensetting van die werkswyse ook verskaf. Die berekeninge wat gebruik is, word met toepaslike werksvoorbeelde verduidelik. Hopelik sal hierdie meettegniek hierdeur wyer in die respirasiefisiologie bekend gestel word.

\section{ABSTRACT}

\section{Measurement of the oxygen binding properties of haemocyanin with the aid of a thin-layer optical cell}

The merits of the thin-layer method of Dolman and Gill ${ }^{7}$ to study the oxygen binding of haemocyanin were experimentally tested with haemocyanin obtained from arthropods and molluscs. The results show that, spectrophotometrically, oxyhaemocyanin from both arthropods and molluscs has a prominent absorption peak between 335 and $345 \mathrm{~nm}$. Haemocyanin is more stable in the thinlayer preparation when compared with haemoglobin. At $35^{\circ} \mathrm{C}$ a decrease in the initial absorbance value of less than $2 \%$ was found after three hours. For haemoglobin the initial value decreases nearly $10 \%$ during the same period. For a high-affinity haemocyanin such as Marisa cornuarietis $\left(P_{50}=1,07 \mathrm{mmHg}\right)$ the thin-layer method of Dolman and Gill $(1978)^{7}$ shows better PO, resolution than other methods. The reason for this is that the dilution valve, which is absent in other thin-layer methods, intrinsically measures the resultant $\mathrm{PO}_{2}$ values at very low tensions more accurately. In this study a step-by-step explanation of the technique is given. The calculations have been explained using real figures and examples. It is hoped that this detailed description will make this technique more readily available for use by respiratory physiologists.

\section{INLEIDING}

Die binding van suurstof aan 'n respirasiepigment soos hemosianien verskaf basiese inligting van die molekule se funksie sowel as sy struktuur. Met hierdie inligting kan die respiratoriese aanpassings wat diere op 'n molekulêre vlak maak, ook geredelik verklaar word. Die respirasiepigment, hemosianien, kom veral by die filums Mollusca en Arthropoda voor. Hierdie twee diergroepe is bekend vir hulle suksesvolle aanpassing in habitatte wat vanaf mariene omgewings tot droë woestyngebiede strek. Sedert die eerste suurstofbindingseienskappe van hemoglobien' en hemosianien $^{2}$ gemeet en as suurstof-hemosianienewewigskrommes (SEK) voorgestel is, is verskeie tegnieke en metodes gebruik om hierdie fisiologiese parameter te meet. Die manometriese metode soos deur Van Slyke en Neill ${ }^{3}$ beskryf, word as die klassieke fisies-chemiese metode beskou. Vir hierdie metode word 'n manometriese analise van die suurstofinhoud van die respirasiepigment by toenemende waardes van die suurstofspanning $\left(\mathrm{PO}_{2}\right)$ gemaak. Die suurstofinhoud in die bloedmonster word gewoonlik op die $\mathrm{y}$-as uitgesit, teenoor $\mathrm{PO}_{2}$-waardes wat op die $\mathrm{x}$-as geplaas word. Die $\mathrm{P}_{50}$-waarde, Bohr-effek en die koöperatiwiteit van die subeenhede van die respirasiepigment kan vanaf 'n "gewysigde" 4 SEK afgelei word. Vir meer inligting oor die gebruikte metodes vir die daarstel vir SEK van rooibloedselsuspensies, heelbloed en hemoglobienoplossings word na twee onlangse publikasies verwys. ${ }^{4,5}$

Die vinnige ontwikkeling die afgelope twee dekades van die vergelykende respirasie-fisiologie het tot gevolg gehad dat die meettegnieke van suurstofbinding met respirasiepigmente ook drasties verander en verfynd geraak het. Van besondere belang in hierdie verband is die ontwikkelinge op die gebied van die dunlaagtegnieke ${ }^{6,7}$ om noukeurige metinge te verkry van die suurstofbindingseienskappe van mikrohoeveelhede respirasiepigment opgelos in 'n bepaalde Ringer. Hiervolgens kon met slegs 10 mikroliterhoeveelhede 'n volledige suurstofewewigskromme gemaak word. 'n Dunlaagmetode wat tot dusver slegs gebruik is vir hemoglobienstudies by mense, soogdiere en kleiner invertebrate, is deur Dolman en Gill ${ }^{7}$ en andere ${ }^{8}$ ontwikkel.

In hierdie publikasie word die meriete van die dunlaag- 
metode van Dolman en Gill ${ }^{7}$ ondersoek om die suurstofbindingseienskappe van hemosianien te meet. Aandag sal aan die spektraaleienskappe van hemosianien en oksihemosianien gegee word om vas te stel watter golflengte die beste vir die metinge gebruik kan word. ' $n$ Belangrike aspek van hierdie verslag is om die tegniek en die bybehorende apparaat en berekeninge só te verduidelik dat navorsers self kan besluit om die tegniek aan te leer.

\section{APPARAATBESKRYWING EN METODES}

\section{(A) Werksbeginsels van die dunlaagmetode}

Die beginsel van die metode is om ' $n$ dunlaaghemosianienoplossing ( $100 \mu \mathrm{m}$ dik) in die optiese weg van ' $n$ gewone spektrofotometer (fig. 1) te plaas. Hiervoor word 'n optiese sel (fig. 2) gebrruik wat, na montering, binne ' $n$ optiese seldraer vasgeklem word (fig. 1). Die seldraer bestaan uit vyf dele naamlik:

(i) 'n plaat met twee boute om die seldraer op die vloer van die spektrofotometer vas te bout;

(ii) koperplate waaraan koperpypies vasgesoldeer is om sodoende, deur watersirkulering, die temperatuur van die seldraer en optiese sel termostaties te beheer;

(iii) 'n gasverdunningsklep wat aan die een kant van die seldraer ingebou is;

(iv) 'n vierkantige koperkamer wat die optiese sel huisves;

(v) 'n metaalhuls waarin ' $n$ suurstofelektrode vertikaal gemonteer is sodat die parsiële suurstofdruk in die klepboor (fig. 3A) en optiese sel gemonitor kan word (kyk later).

Die dun hemosianienlaag in die optiese sel (fig. 3A) rus op 'n gestrekte membraan (MEM 213, silikoonpolikarbonaat, General Electric Co. USA) wat UV-lig en die normale gasse soos stikstof en suurstof deurlaat. Die hemosianienlagie word vertikaal georiënteer ten opsigte van die optiese ligpad. Die dikte van die laag kan verander word met die hulp van vlekvryestaalwasters wat van 25 mikrometer tot 100 mikrometer dik is.

Met die verdunningsklep word die hemosianienmonster blootgestel aan stapsgewys afnemende parsiële suurstofdrukke terwyl die suurstofversadiging van die monster, by elke stap, spektrofotometries gemonitor word.

(B) Voorbereiding van die hemosianienmonster in die optiese sel (fig. 2)

1. Steek 'n steunstuk in die vlekvryestaalselliggaam van die optiese sel en skroef dit met twee boutjies vas. Die steunstuk help met die egalige strekking van die membraan en om die hemosianienmonster aanvanklik te ondersteun.

2. Plaas die wydste kant van die dun nylonring (nr) op die monteernek $(\mathrm{mn})$ van die vlekvryestaalblok en druk die nylonring oor die nek sodat die een vlak van die nylonring gelyk lê met die monteernek se bo-vlak.

3. Plaas die ronde ( $16 \mathrm{~mm}$ in deursnee) silikoonpolikarbonaatmembraan bo-oor die nylonring en monteernek. Neem die dik nylonring en druk sy opening versigtig teen die membraan. Met' $n$ stewige drukbeweging word die dik nylonring oor die membraan gedruk tot teenaan die skouer van die selliggaam.

4. Plaas ' $n$ filmlagie gehalogeneerde koolstofghries (Halocarbon 25-5S, Halocarbon Products Co. Hackensak, N.J. VSA) tussen die duim en wysvinger. Ghries die vlekvryestaalwaster liggies aan beide kante. Plaas die waster versigtig op die membraan en druk liggies vas.

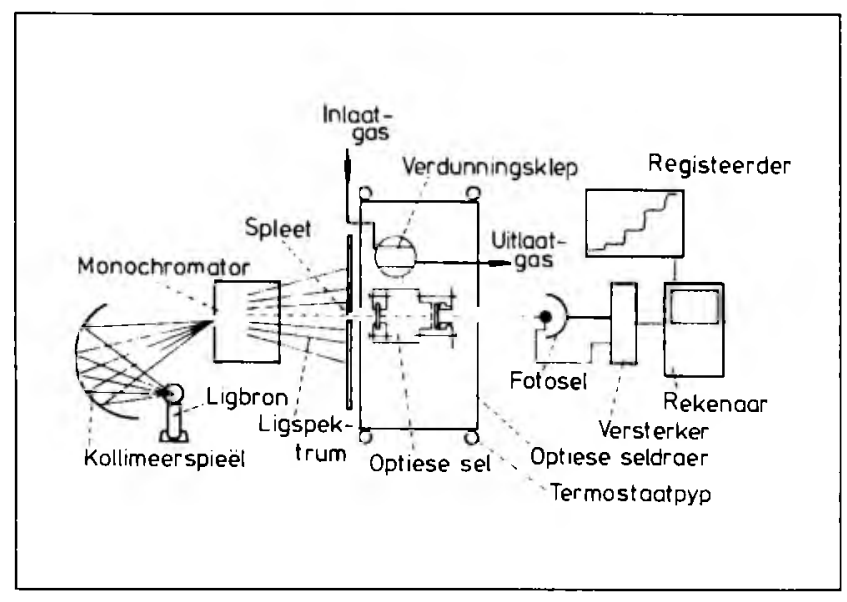

FIGUUR I: 'n Diagrammatiese voorstelling van die spektrofotometer, optiese sel, seldraer, rekenaar en registreerder vir die meting van die suurstofbindingseienskappe van hemosianien. Die figuur is nie volgens skaal geteken nie. Die verkoeler en termostaat is uit die figuur weggelaat.

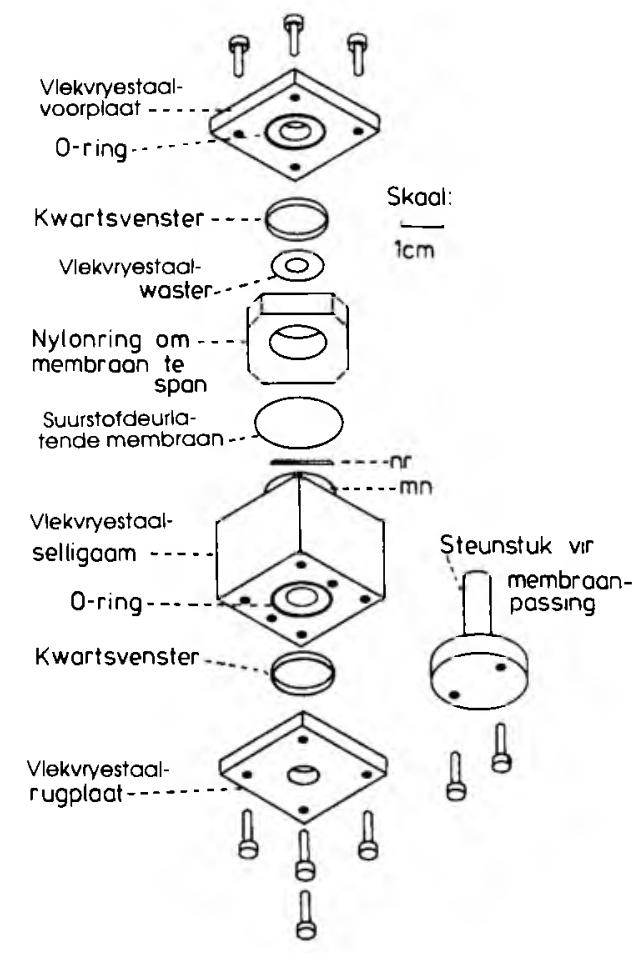

FIGUUR 2: 'n Uitmekaargehaalde optiese sel. Die vlekvryestaalvoorplaat kan, in' $n$ gewysigde vorm, vervang word met ' $n$ metaaldrukring en veerplaat soos in figuur $3 A$ aangedui is; $n r$, nylonring; mn, monteernek. 

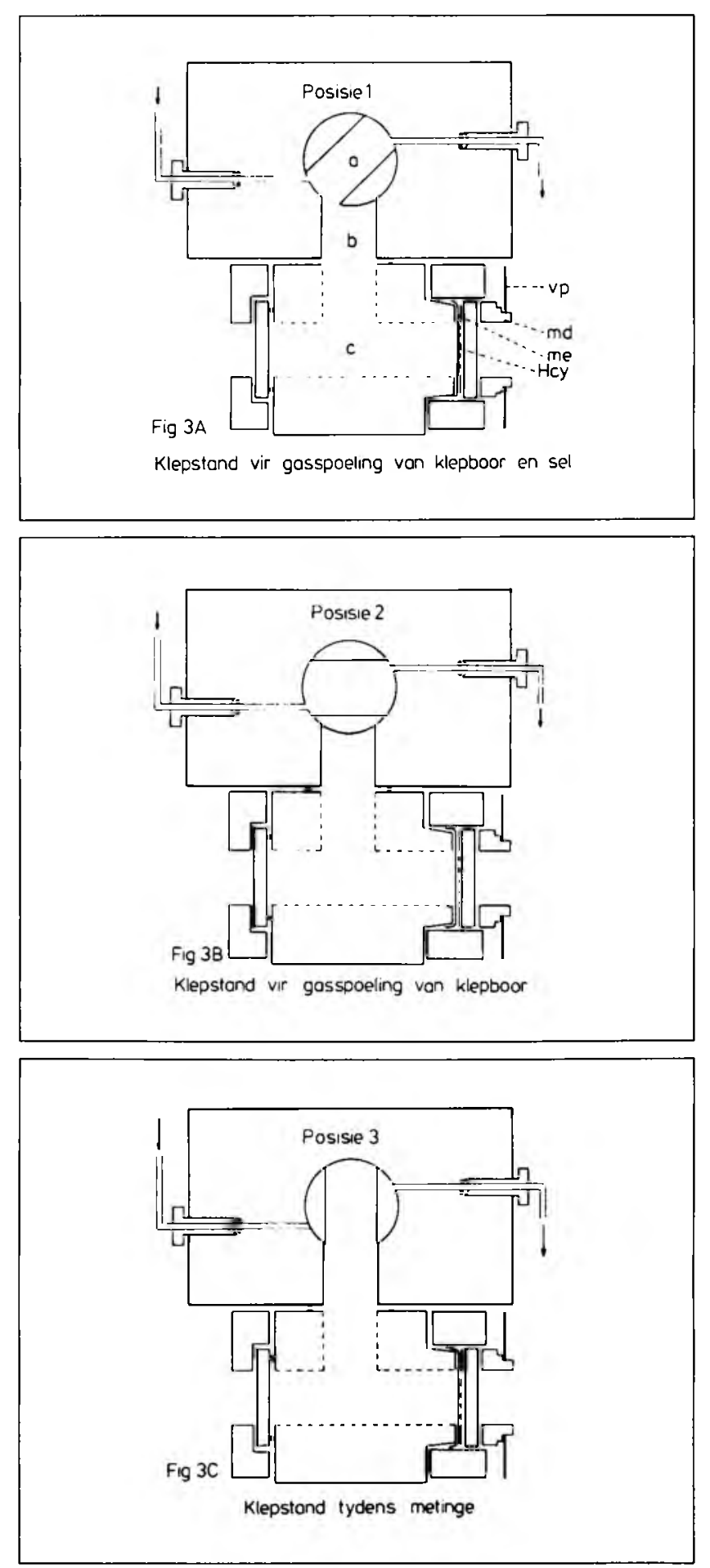

FIGUUR 3: 'n Snit deur die verdunningsklep en optiese sel om die werking van die verdunningsklep te illustreer. $3 A$, die kraan met boor is gedraai sodat die verskillende gasse die klepboor en sel kan deurspoel; a, volume van selboor; $b$, volume van seldraer; $c$, volume van sel. ' $n$ Gas $x$ in a sal die gas $\boldsymbol{y}$ in $\boldsymbol{b}+\boldsymbol{c}$ van $100 \%$ na $70,4 \%$ verdun as die klepstand van posisie 2 na posisie 3 gedraai word; Hcy, hemosianienlagie; me, membraan; md, metaaldrukring; $v p$, veerplaat. $3 B$, die kraan van die klep by posisie 2 voldoen aan twee funksies naamlik om die "ou" gas van die klepboor te verwyder en om 'n nuwe gas (gewoonlik $N_{2}$ ) in die klepboor te plaas. $3 C$, posisie 3 is die klepstand tydens die metinge waar die "nuwe" gas vanaf a na b en $\boldsymbol{c}$ diffundeer totdat 'n ewewig van alle gasse in die ruimtes en in die hemosianienlagie ( $\mathrm{Hcy}$ ) bereik is.
5. Plaas met die hulp van 'n tienmikroliterpipet 'n oplossing van hemosianien op die membraan sonder om met die pipetpunt aan die membraan te raak.

6. Plaas so gou moontlik ' $n$ kwartsvenster bo-oor die monster deur die kwartsvenster aan die een kant teen die membraan en dik nylonring te steun en versigtig te laat sak. Sorg dat 'n egalige lagie hemosianienoplossing gevorm word sonder die vorming van lugblasies.

7. Plaas die vlekvryestaalvoorplaat oor die kwartsvenster en skroef dit vas met die vier boutjies.

8. In die plek van die vlekvryestaalvoorplaat kan ook 'n metaaldrukring ( $m$ d) en 'n veerplaat ( $v p$ ) gebruik word (fig. 3A). In die geval van hierdie modifikasie word die vier boutjies deur die veerplaat se gate gesteek en word die veerplaat en metaaldrukring stewig aan die vlekvryestaalselliggaam vasgebout.

9. Verwyder die steunstuk stadig uit die selliggaam en monteer nog 'n kwartsvenster met die hulp van die rugplaat en vier boutjies aan die selliggaam vas.

10. Inspekteer die monster en membraan vir lugblasies of voue. Plaas ' $n$ opgerolde filtreerpapier $(6 \mathrm{~mm} \mathrm{x}$ $25 \mathrm{~mm}$ ) in die beginpoort van die optiese sel en versadig dit met 20 mikroliter bufferoplossing soortgelyk aan die elektrolietsamestelling van die hemosianienmonster.

(C) Montering van die optiese sel en werking van die verdunningsklep

1. Plaas die optiese sel in die kamer van die optiese seldraer sodat die membraankant in die rigting van die fotovermenigvuldiger van die spektrofotometer wys (fig. 1). Dra sorg dat die beginpoort van die sel presies oor die poort van die seldraer, wat na die klep lei, pas. Skroef die sel met die hulp van die drukplaat en bout stewig vas.

2. Werking van die verdunningsklep

2.1 Posisie 1 (fig. 3A)

Gasspoeling van die klepboor en sel

By hierdie posisie van die klep word die hemosianienmonster blootgestel aan lugsuurstof en koolsuurgas van 'n voorafbeplande persentasiesamestelling.

2.2 Posisie 2 (fig. 3B)

Gasspoeling van die klepboor

Die klepboor word afgesluit van die poorte in die optiese sel. By hierdie posisie word die klepboor met gas, gewoonlik stikstof, gemang met koolsuurgas, deurspoel om die gasmengsel (gewoonlik lugsuurstof gemeng met $2 \%$ tot $5 \%$ koolsuurgas) te vervang.

2.3 Posisie 3 (fig. 3C)

Klepstand tydens metinge

Wanneer die klepboor met die poort van die optiese sel verbind word, sal die klepboor se suurstofvrye volume (posisie 2) met die lugsuurstof in die optiese sel vermeng en sodoende die $\mathrm{PO}_{2}$ in die optiese sel verminder. Omdat die diffusiekonstante van suurstof in lug 3,0 x 10 $0^{5}$ keer vinniger in lug as in water is, ${ }^{9}$ sal die suurstof en stikstof binne sekondes met mekaar meng en in ewewig wees. Die diffusie van 


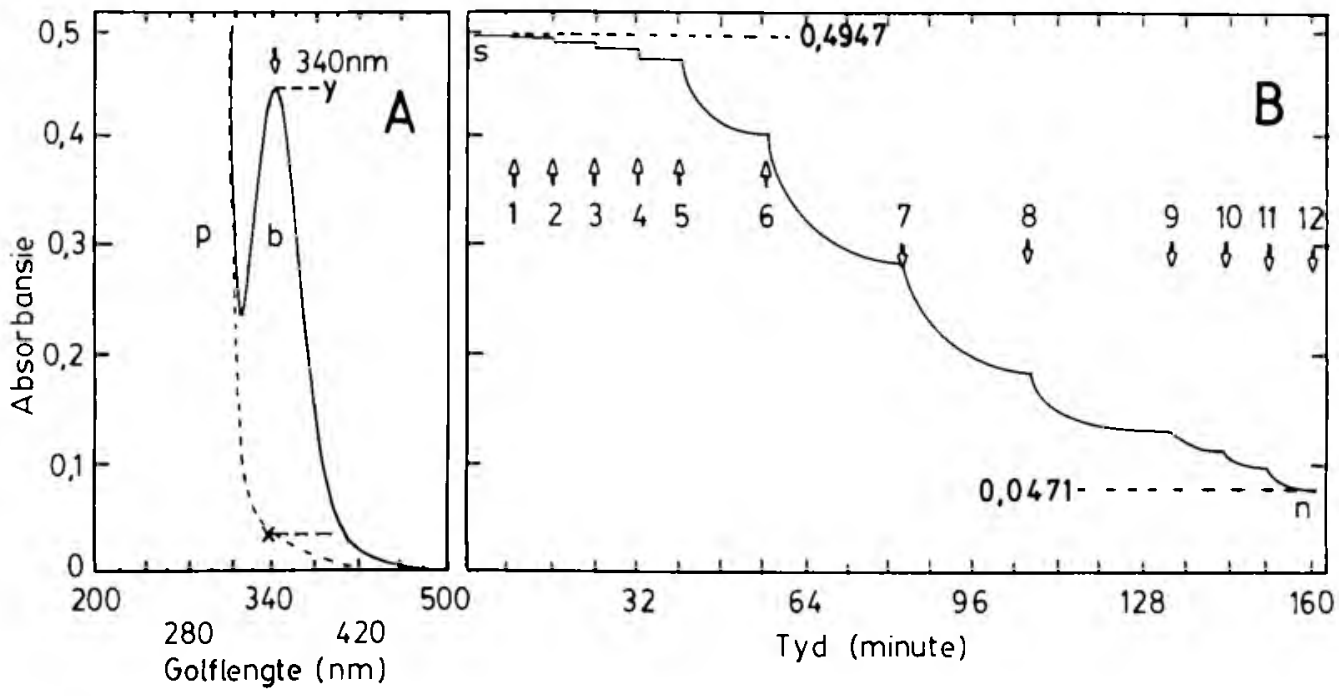

FIGUUR 4: Absorbansiedata van hemosianien. (4A) Nagetekende spektrum van 'n hemosianienoplossing; b, absorpsiepiek van oksihemosianien. p, gedeeltelike absorpsiepiek van proteïn; $x$, absorpsie van hemosianien. Die vermindering van die absorbansie van $\boldsymbol{y}$ na $\boldsymbol{x}$ is direk eweredig met die vermindering van die suurstofinhoud van die hemosianienmonster (4B). Nagetrekte registreerderdata van die absorbansieverandering by $339 \mathrm{~nm}$ versus tyd by 'n suksessie van 12 gasverdunnings met stikstof. Die absorbansiewaarde by $\boldsymbol{S}$ is die aanvangswaarde en by $\boldsymbol{n}$ is dit die endwaarde nadat stikstof deur sowel die klepboor as die sel gespoel is by stand $3 C$ (figuur 3). Hierdie absorbansiewaardes is as werksvoorbeelde in die berekeninge gebruik.

hierdie gasmengsel word voortgesit in die gasdeurlatende membraan en die lagie water met hemosianien. Na 1 tot 5 minute word 'n ewewigstoestand geskep tussen die ruimtes van die sel en klepboor en die lagie hemosianienoplossing.

2.4 Ná posisie 3 word die klep weer teruggedraai na posisie 2 toe en die volgende stikstofspoel met $\mathrm{CO}_{2}$ van die klepboor vind dan plaas. Word die klep weer na posisie 3 gedraai, word verdunningstap 2 in werking gestel. Virhemosianien met 'n hoësuurstofaffiniteit is tot 20 en meer verdunningstappe nodig. Vir 'n laesuurstofaffiniteit-hemosianien is 10 verdunningstappe gewoonlik voldoende. In fig. 4 is daar van 12 verdunningstappe gebruik gemaak.

Die verdunningsklep lyk baie soos 'n kegelvormige, geslypte glaskraan met sy huls waarvan die boor egter baie groter is (figure $1 \& 3 \mathrm{~A}$ ). Die klep, waarvan die binnedeel uit vlekvrye staal en die buitenste huls uit geelkoper gemaak is, funksioneer tesame met die klepboor, as 'n gasverdunningsmeganisme vir die optiese sel se binnevolume. Die gasverdunningsverhouding van die klep se boor en die sel se binnevolume kan bepaal word deur die klepboor en die binnevolume van die sel met water te vul. ' $n$ Ander metode om die verdunningsverhouding vas te stel, is deur die gebruik van die suurstofelektrode wat met die boor van die klep in verbinding is. Beide metodes gee ' $n$ verdunningsfaktor, $Q$ van $0,708 \pm 0,002$ aan. Dit beteken dat die parsiële suurstofdruk $\left(\mathrm{PO}_{2}\right)$ binne die sel verminder van $100 \%$ na $70,8 \%$ vir elke opvolgende verdunningstap.

(D) Berekening van die $\mathrm{PO}_{2}$ by elke verdunningstap As die $\mathrm{PO}_{2}$ binne die optise sel, na die uitvoering van posisie 1 (fig. 3A) bekend is, kan die $\mathrm{PO}_{2}$ in die optiese sel vir elke verdunningstap met die hulp van die verdunningsfaktor, $\mathrm{Q}$, bereken word. ${ }^{7}$

$$
P_{i}=Q_{P-1}+\frac{n\left(\theta_{i-1}-\theta_{i}\right) R T}{V}
$$

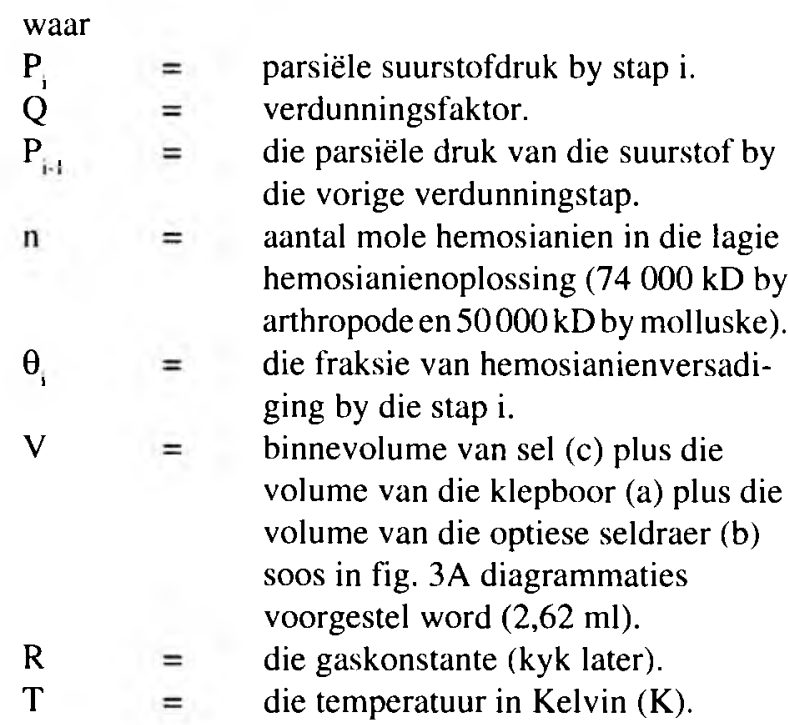

(E) Werksvoorbeeld

Die volgende data is ' $n$ werksvoorbeeld om $P_{\text {, }}$ te bepaal en word in $\mathrm{mmHg}$ aangegee. Die eksperimentele temperatuur is $278 \mathrm{~K}\left(5^{\circ} \mathrm{C}\right)$.

1. Die fraksieversadiging (1) van die hemosianienmonster by die i-ste stap moet eers bekend wees:

\footnotetext{
Absorbansiehemosianien (i-ste stap) - Abs.hemosianien Abs.oksihemosianien - Abs.hemosianien

$=\frac{0,0471-0,4947}{0,0468-0,4947}$

$=0,9993302(99,93 \%$ versadiging van die hemosianien met
} suurstof) 
2. Berekening van $P_{i}$ $\mathrm{P}_{1}$ word bereken en die $\mathrm{PO}_{2}$ wat van die hemosianien vrykom word bygetel:

$$
\begin{aligned}
P_{1} & =\frac{0,708 \times 154,8+4,2 \times 10^{9}(1-0,993302) R T}{V} \\
& =\frac{109,59+4,2 \times 10^{-9}(0,000698 \times 62,37 \times 278)}{V}
\end{aligned}
$$$$
=109,598 \mathrm{mmHg}
$$

Die waarde van die gaskonstante, $\mathrm{R}$, is $8,314 \mathrm{JK}^{1}$ mol $^{-1}$ en word 0,08205 liter-atmosfeer $\mathrm{K}^{-1}$ mol $^{-1}$. As dit uitgedruk word in $\mathrm{mmHg} \mathrm{K} \mathrm{Kol}^{-1}$, word die waarde:

$$
\begin{aligned}
R & =82.05 \times \frac{1}{1000} \times \frac{760}{1} \mathrm{~K}^{-1} \mathrm{~mol}^{-1} \\
& =62,37 \mathrm{mmHg} \mathrm{K}^{-1} \mathrm{~mol}^{-1}
\end{aligned}
$$

Die data van berekeninge (1) op die y-as en (2) op die $\mathrm{x}$-as kan grafies voorgestel word as ' $\mathrm{n}$ suurstofewewigskromme. As verkies word om data (1) en (2) op 'n Hillgrafiek voor te stel, word data (1) as die Hillkoëffisiënt voorgestel:

$$
\begin{aligned}
\text { Hillkoeffisient } & =\log \left(\frac{\text { fraksieversadiging }}{1-\text { fraksieversadiging }}\right) \\
& =\log \left(\frac{0,9993302}{1-0,9993302}\right) \\
& =\log (1491,9) \\
& =3,173 \ldots \ldots \ldots \ldots \ldots \ldots \ldots \ldots \ldots \ldots \ldots \ldots \ldots \ldots \ldots \ldots
\end{aligned}
$$

(F) Bepaling van hemosianienkonsentrasie

Die hemosianienkonsentrasie van 'n hemolimfmonster kan spektrofotometries bepaal word met behulp van die optiese sel of met die konvensionele Kuvetmetode, indien die uitwissingskoëffisiënt van die hemosianien bekend is.

\section{Optieseselmetode}

Maak 'n hemosianienpreparaat met die hulp van die optiese sel. Plaas die sel in die optiese pad van die spektrofotometer by $335 \mathrm{~nm}$ en bepaal die absorbansiewaarde. Die uitwissingskoëffisiënt van die hemosianien by krappe $^{10}$ is $2,69=1 \% / 1 \mathrm{~cm}$ by $335 \mathrm{~nm}$ ( = uitwissingkoëffisiënt, $1 \%=1 \mathrm{~g}$ hemosianien opgelos in 100 $\mathrm{ml}$ water, $1 \mathrm{~cm}=$ optiese weglengte in sentimeters). Die hemosianienkonsentrasie kan met die volgende werksvoorbeeld bereken word:

Hemosianienkonsentrasie $(\mathrm{mg} / \mathrm{ml})$ :

Absorbansie

Uitwissingskoëffisiënt (E) $\mathrm{x}$ weglengte $(\mathrm{cm})$

Die weglengte van die lagie hemosianien in die optiese sel is $0,0127 \mathrm{~cm}$.

$$
=\frac{0,448}{2,69 \times 0,0127}
$$

$=13,1 \%$

$=131,0 \mathrm{mg}$ hemosianien per milliliter.

\section{Kuvetmetode}

As dieselfde konsentrasie hemosianien as ' $n$ volume van 20 mikroliter in ' $\mathrm{n}$ kwartskuvet ( $1 \mathrm{~cm}$ weglengte) in $2 \mathrm{ml}$ krap Ringer gepipeteer word en die absorbansie word gemeet, kan die hemosianienkonsentrasie met die volgende werksvoorbeeld bereken word;

Hemosianienkonsentrasie $=\frac{\text { Absorbansie }}{\text { Uitwissingskoëffisiënt } \mathrm{x} \text { weglengte }}$
V VF

Waar, VF, die verdunningsfaktor is:

$=\frac{0,353}{2,69 \times 1} \times 100$

$=13,1 \%$

$=131 \mathrm{mg}$ hemosianien per milliliter water.

Die Kuvetmetode is meer noukeurig omdat die weglengte in die optiese sel kan varieer as gevolg van die variasie in die drukking van die voorplaat/veerplaat. As die hemosianienhoeveelhede baie min is, soos wat dit soms die geval is by diere wat in klein getalle voorkom of baie klein diereksemplare, kan die optieseselmetode gebruik word.

Voordat die verskillende parameters in 'n rekenaarprogram ingevoer word (kyk later), moet die getal mole hemosianien teenwoordig in die hemosianienlagie in die optiese sel bereken word. Die molekulêre massa van kraphemosianien is 74900 Dalton. ${ }^{10}$ Met die volgende werksvoorbeeld kan die getal mole hemosianien bereken word:

$$
\begin{aligned}
& \begin{array}{l}
\text { Mole } \\
\text { hemosianien }
\end{array}=\frac{\text { konsentrasie hemosianien }}{\text { molekulêre massa }} \times \frac{6,38}{1000000} \\
& =1,11 \times 10^{-8} \text { mole hemosianien in die } \\
& \text { lagie hemosianien met ' } n \text { volume van } \\
& 6,38 \text { mikroliters. }
\end{aligned}
$$

(G) 'n Werksvoorbeeld van die waardes wat in 'n rekenaarprogram ingevoer word om $\log \mathrm{PO}_{2}$ en $\log \frac{\theta}{1-\hat{\theta}}$ te verkry vir die uitsit van 'n Hillgrafiek

1. Die absorbansie van oksihemoglobien : 0,448 .

2. Die absorbansie van hemosianien : 0,024 .

3. Mole hemosianien in hemosianienlagie : $1,11 \times 10^{-8}$.

4. Volume van sel en klepboor : 0,00262 liter.

5. Verdunningsfaktor van gasse in sel : 0,708 .

6. Die aanvangs $-\mathrm{PO}_{2}$ by stap nul : $131,0 \mathrm{mmHg}$.

7. Die temperatuur van die monster in $\mathrm{K}: 298$.

8. Die getal verdunningstappe : 15 .

Die rekenaarprogram is in Pascal geskryf $\mathrm{f}^{8}$ sodat die berekeninge gemaak word vir die uitstip van die volledige suurstofewewigskromme of die Hillgrafiek. Die resultate word in tabel 1 weergegee. 


\section{RESULTATE, BESPREKING EN GEVOLGTREKKING}

\section{Die noukeurigheid van die $\mathrm{PO}_{2}$-metinge}

Omdat van 'n verdunningsklep gebruik gemaak word om die waardes van $\mathrm{PO}_{2}$ te bepaal in plaas van Wösthoff-gasmengpompe, ${ }^{4}$ kan die noukeurigheid bevraagteken word. Om die noukeurigheid van die verdunning te toets, is die herhaalbaarheid van die metinge 5 keer vir elke verdunningstap vir 15 stappe gemeet. Volgens die resultate (fig. 5) val al die punte op die helling met 'n foutgrens van $0,2 \%$. Vir 20 verdunningstappe kan 'n fout van $4 \%$ geakkumuleer word. Hierdie foutgrens val egter binne die bestaande noukeurigheid van die Clark polarografiese elektrode. ${ }^{4}$

Uit die resultate (fig. 6) blyk dit dat die hemosianienlagie in die optiese sel, wat sy bindingseienskappe met suurstof betref, besonder stabiel bly. Drie uur na preparering het die absorbansiewaarde ' $n$ vermindering van ongeveer $1,5 \%$ vertoon by ' $\mathrm{n}$ blootstellingstemperatuur van $35^{\circ} \mathrm{C}$. By $10^{\circ} \mathrm{C}$ was die absorbansie-afname na drie uur $0,2 \%$. Volgens fig. 6 is dit duidelik dat hemoglobien funksioneel baie onstabiel is wanneer dit as ' $n$ dun lagie geprepareer word. Ander navorsers ${ }^{4,8}$ het ook hierdie probleem met hemoglobien ondervind.

As die suurstofbinding van 'n hoësuurstofaffiniteithemosianien van die slak Marisa cornuarietis byvoorbeeld gemeet word, " kan dit met 'n groter mate van noukeurigheid deur hierdie dunlaagmetode gedoen word as met ander metodes. Dit is so omdat by verdunningstap 18 (tabel 1) byvoorbeeld ' $\mathrm{P} \mathrm{PO}_{2}$ van $0,172 \mathrm{mmHg}$ deur die verdunningsklep by 'n barometriese druk van $656 \mathrm{mmHg}$ afgemeet kon word. Behalwe vir Sick en Gersonde ${ }^{6}$ en hierdie gebruikte

\section{TABEL 1}

'n Voorbeeld van die $\mathrm{PO}_{2}$-waardes (mmHg) en die fraksieversadiging $(\%)$ van 'n hoëaffiniteit-hemosianienmonster met suurstof wat respektiewelik deur die verdunningsklep $\left(\mathrm{PO}_{2}\right.$ ) geregenereer is en spektrofotometries (fraksieversadiging) gemeet is. Die data is verkry van die varswaterslak Marisa cornuarietis by 'n barometriese druk van $656 \mathrm{mmHg}$

\begin{tabular}{|c|c|c|}
\hline Gasverdunningstappe & $\begin{array}{l}\mathrm{PO}_{2} \text {-waardes } \\
(\mathrm{mmHg})\end{array}$ & $\begin{array}{l}\text { Fraksieversadiging } \\
\text { van hemosianien } \\
\text { met suurstof }(\%)\end{array}$ \\
\hline $\begin{array}{l}0 \\
1 \\
2 \\
3 \\
4 \\
5 \\
6 \\
7 \\
8 \\
9 \\
10 \\
11 \\
12 \\
13 \\
14 \\
15 \\
16 \\
17 \\
18\end{array}$ & $\begin{array}{r}131,31 \\
90,52 \\
62,55 \\
43,22 \\
29,86 \\
20,86 \\
14,26 \\
9,85 \\
6,81 \\
4,70 \\
3,25 \\
2,25 \\
1,55 \\
1,07 \\
0,74 \\
0,51 \\
0,35 \\
0,24 \\
0,17\end{array}$ & $\begin{array}{l}100 \\
99,17 \\
98,34 \\
97,52 \\
96,69 \\
95,86 \\
95,04 \\
94,21 \\
91,73 \\
88,42 \\
82,64 \\
72,72 \\
61,98 \\
50,41 \\
40,49 \\
33,88 \\
29,75 \\
26,44 \\
23,96\end{array}$ \\
\hline
\end{tabular}

dunlaagmetode kan geen ander meettegniek dergelike presiese $\mathrm{PO}_{2}$-konsentrasies afmeet nie. Hierdie vermoë van die twee dunlaagmetodes maak dit baie geskik om hoësuurstofaffïniteit-hemosianien betroubaar te meet. Die meting van hemosianien se respiratoriese eienskappe kon aanvanklik slegs by mariene slakke en krappe wat groot hoeveelhede hemolimf bevat, gedoen word. ${ }^{2}$ Sodoende kon, met betreklik eenvoudige manometriese analise en gasvermenging $\left(\mathrm{O}_{2}, \mathrm{~N}_{2}\right.$, $\mathrm{CO}_{2}$ ), 'n SEK opgestel word. Hoewel die vervanging van die manometer deur die spektrofotometer heelwat verbeterings gebring het in die noukeurigheid en spoed van die analise van die hoeveelheid suurstof gebind aan hemosianien, was dit nog prakties onmoontlik om SEK te maak van klein volume monsters. Met die dunlaagmetode wat hier getoets

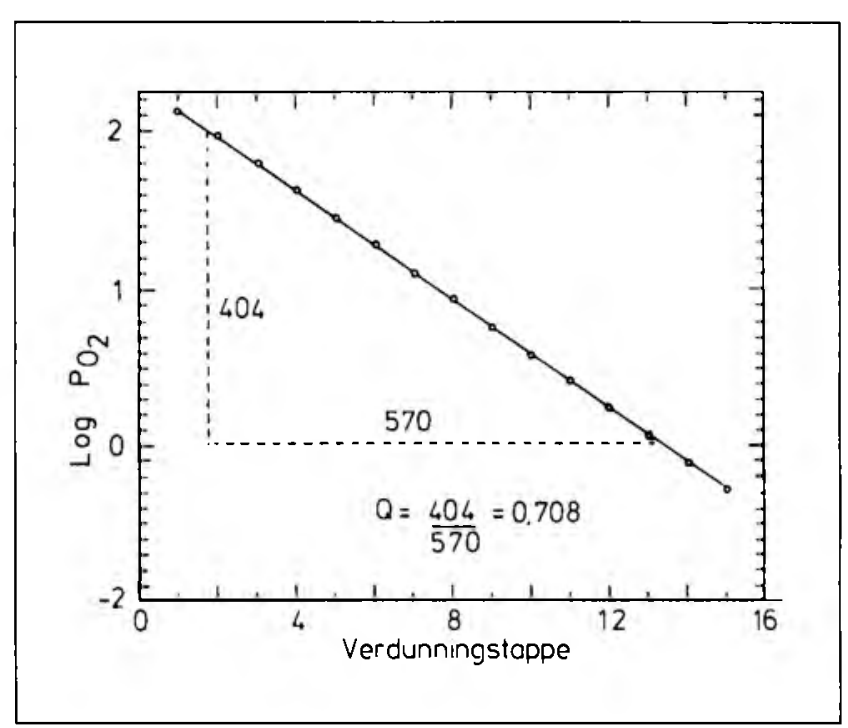

FIGUUR 5: 'n Grafiese voorstelling van die log- $\mathrm{PO}_{2}$-waardes in $\mathrm{mmHg}$ wat verkry is van 15 verdunningstappe van lug as begingas in die optiese sel. Die helling gee ' $n$ Q-faktor van 0.708 wat die verdunningsverhouding is by $20^{\circ} \mathrm{C}$ met Marisa cornuarietis se hemosianien.

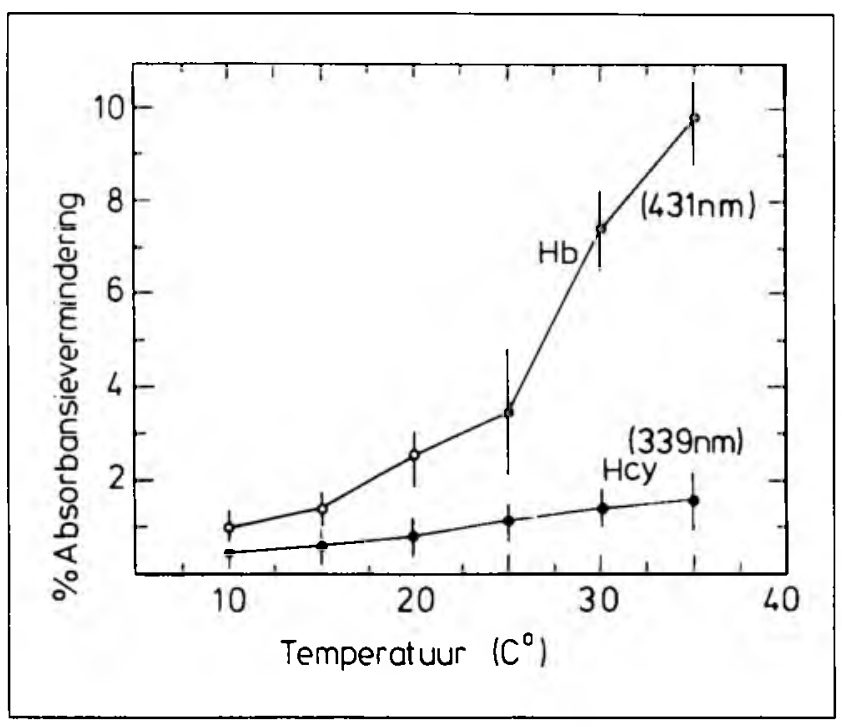

FIGUUR6: 'n Vergelyking tussen hemoglobien (Hb, Bulinus) en hemosianien-stabiliteit (Hcy, Marisa) in die optiese sel by toename in temperatuur. Die persentasie absorbansievermindering tussen die beginwaarde en die endwaarde is na drie uur, vir elke temperatuur, vasgestel by 339 nanometers vir hemosianien en by $431 \mathrm{~nm}$ vir hemoglobien. 
is, kan nou van mikrohoeveelhede hemosianienmonsters gebruik gemaak word. Dit hou die moontlikheid in dat die SEK van individuele skerpioene, spinnekoppe en ander artropode van kleiner as een gram in massa, hiermee bepaal kan word. Die absorbsiepiek by $335 \mathrm{~nm}$ vir artropode en 345 $\mathrm{nm}$ vir molluske is beter geskik vir suurstofbindingstudies as die breë absorbsiepiek tussen 500 en $600 \mathrm{~nm}$. Laasgenoemde piek, wat vir die blou kleur van die respirasiepigment verantwoordelik is, is ongeveer tien keer kleiner as die absorbsiepiek in die UV-gebied.

Die dunlaagtegniek van Dolman en Gill ${ }^{7}$ wat hier gebruik is om SEK en Hillgrafieke daar te stel, word hoofsaaklik in die laboratoriums van dr. S. Gill in Boulder, Colorado en by dr. A. Riggs in Austin, Texas gebruik. Die dunlaagtegniek van Sick en Gersonde, ${ }^{\circ}$ aan die ander kant, word meesal in laboratoriums in Europa gebruik. Laasgenoemde tegniek is beter bekend by dierfisioloë $\ddot{e}^{4}$ terwyl die berekinge om $\mathrm{PO}_{2}$ te verkry makliker is. Die voorbereiding van die hemosianienmonster in ' $n$ spesiale optiese sel is nie nodig nie. ' $n$ Groot nadeel van Sick en Gersonde se metode is dat 'n spesiale tipe spektrofotometer/fotometer en monsterkamer nodig is en die $\mathrm{PO}_{2}$-waardes deur ten minste twee Wösthoffgasmengpompe gegenereer moet word. Daarenteen kan die dunlaagmetode van Dolman en Gill met 'n gewone spektrofotometer gedoen word sonder die gebruik van die duur gasmengpompe. Dit kan ook hoë konsentrasies hemosianien hanteer. Met 'n rekenaarprogram kan die Q-verhouding, wat eers met 'n suurstofelektrode gekonroleer is, in stappe, as $\mathrm{PO}_{2}$-waardes bereken word. Hopelik sal die bekendstelling van hierdie tegniek, en die feit dat dit die suurstofbindingseienskappe van hemosianien betroubaar kan meet, dierkundiges in staat kan stel om hierdie belangrike fisiologiese meting by invertebraatdiere te kan uitvoer.

\section{DANKBETUIGINGS}

Die Potchefstroomse Universiteit vir $\mathrm{CHO}$ en die Stigting vir Navorsingsontwikkeling word bedank vir die beskikbaarstelling van die nodige navorsingsfasiliteite en fondse. Dr. S. Gill, Boulder, Colorado word bedank vir die maak en verskaffing van die optiese sel en verdunningsklep.

\section{LITERATUURVERWYSINGS}

1. Bohr, C. (1904). Theoretische Behandlung der quantitativen Verhaltnis bei der Sauerstofaufname des Hamoglobins, Abl. Physiol., 17, 682 692.

2. Begemann, H. (1924). Over de ademhalingsfunctie van haemocyanine. Proefskrif, Universiteit van Utrecht, Utrecht.

3. Van Slyke, D.D. \& Neill, J.M. (1924). The determination of gases in blood and other solutions by vacuum extraction and manometric measurement, J. Biol. Chem., 61, 523 - 573.

4. Weber, R.E. \& Wells, R.M.G. (1988). The measurement of oxygen affinity in blood and haemoglobin solutions. In: Techniques in comparative respiratory physiology, Bridges, C.R. \& Butler, P.J. eds. (Cambridge Univ. Press, Cambridge) p. 279.

5. Asakura, T. \& Reilly, M.P. (1986). Methods for the measurement of oxygen equillibrium curves of red cell suspensions and hemoglobin solutions. In: Oxygen Transport and Red Blood Cells, vol. 54, Advances in the Bio-sciences, ed. Nicolau, C. (Pergamon Press, Oxford) p. 57.

6. Sick, H. \& Gersonde, K. (1972). Method for continuous registration of $\mathrm{O}_{2}$-binding curves of hemoproteins by means of a diffusion chamber, Anal. Biochem., 32, 362 - 376.

7. Dolman, D. \& Gill, S.J. (1978). Membrane-covered thin-layer optical cell for gas-reaction studies of hemoglobin, Anal. Biochem., 87, 127 134.

8. Van Aardt, W.J. \& Naude, K. 1990. Effects of buffer composition, pH and temperature on oxygen binding by planorbid snail haemoglobins, $S$. Afr. J. Zool., 25, $18-25$.

9. Schmidt-Nielsen, K. (1990). Animal physiology. Adaptation and environment (Cambridge Univ. Press, Cambridge).

10. Nickerson, K.W.\& Van Holde, K.E. (1971). A comparison of molluscan and arthropod hemocyanin. 1. Circular dichroism and absorption spectra, Comp. Biochem. Physiol, 39B, 855 - 872.

11. Van Aardt, W.J. \& De Kock, K.N. (1991). Oxygen consumption and haemocyanin function in the freshwater snail Marisa cornuarietis (L.), Comp. Physiol. Biochem. (in press). 